\title{
COMPOSTED SEWAGE SLUDGE IN REPLACEMENT OF MINERAL FERTILIZATION ON WHEAT PRODUCTION AND DEVELOPMENT ${ }^{1}$
}

Doi:http://dx.doi.org/10.1590/1809-4430-Eng.Agric.v36n4p706-714/2016

\section{ANA C. B. KUMMER ${ }^{*}$, HELIO GRASSI FILHO ${ }^{3}$, THOMAZ F. LOBO ${ }^{4}$, RODOLLPHO A. DE S. LIMA ${ }^{5}$}

\begin{abstract}
Several research lines are required to ensure a proper disposal of sewage sludge in Brazil; among them, we may highlight agricultural use. In this sense, this study aimed at assessing the effect of exchanging nitrogen sourcing via conventional fertilization (chemical) with growing doses of composted sewage sludge (CSS) on wheat crop performance. The experiment was performed in a completely randomized design with seven treatments and ten replications, being defined as T0 (control - without fertilization); T1 (100\% mineral fertilization); T2 (50\% mineral + 50\% CSS); T3, T4, T5, and T6 (100, 150, 200, and 250\% nitrogen fertilizing from CSS). Results showed that the use of CSS increased wheat production and development, therefore enhancing its performance. Thus, exchanging mineral fertilization with CSS application raised wheat yields.
\end{abstract}

KEY WORDS: nitrogen, organic fertilization, production, Triticum aestivum.

\section{INTRODUCTION}

Even though most Brazilian cities have no sewage collection and treatment system, sludge generation has increased due to population growth and socio-economic development, bringing great concern since this residue is produced in large scale. Therefore, in order to ensure a proper disposal of the sewage sludge (SS), several research lines have to be encompassed in Brazilian studies, such as agricultural uses for instance.

The SS is rich in organic matter and other key elements, being able to substitute the mineral fertilization, which plays an important role in agricultural development, keeping soil fertility (NOGUEIRA et al., 2008) and decreasing fertilization costs.

In Brazil, numerous studies have shown benefits from using SS in farming areas either for recovery of degraded areas (TEIXEIRA et al., 2007) or as partial or total fertilization of soils under forestry (ANDRADE et al., 2005; PELISSARI et al., 2009), fruit plantation (COELHO, et al., 2011) or crops as cotton, wheat, sugarcane, soybean, black oat, sunflower, among others (FIGUEIRÊDO et al., 2005; CHUEIRI et al., 2007; CHIBA et al., 2008; BEHLING et al.; 2009; ; LOBO et al., 2012a; LOBO et al., 2013).

According to BOEIRA (2004), SS may release a large amount of mineral nitrogen into the soil solution few days after application, as long as conditions for organic matter mineralization are provided. All the same, LOBO et al. (2012b) reported that after composting with other farming residues, sludge $\mathrm{C} / \mathrm{N}$ ratio might reach values acceptable levels and considered suitable for application to the soil without causing major problems to the environment for nitrogen excess.

Since nitrogen is the most required nutrient for wheat plants, and it has a complex dynamics within the soil in which could be lost by leaching and volatilization (TEIXEIRA FILHO, et al., 2008), many recent researches have aimed to assess wheat yields at varied doses of applied nitrogen, different cultivars and sowing densities (ZAGONEL et al., 2002; TEIXEIRA FILHO et al., 2008; VIANA \& KIEHL, 2010; NUNES et al., 2011; PRANDO et al. 2012; COSTA et al., 2013); however, few of them deal with SS use.

\footnotetext{
${ }^{1}$ Part of the first author's PhD. dissertation.

${ }^{2}$ UEPG/Ponta Grossa - PR, Brasil.

${ }^{3}$ UNESP/Botucatu - SP, Brasil.

${ }^{4}$ Universidade Sagrado Coração, USC/ Bauru - SP, Brasil.

${ }^{5}$ UENF/Campos do Goytacazes - RJ, Brasil.

*Corresponding author. E-mail: ackummer@hotmail.com

Received in: 4-16-2014

Accepted in: 6-16-2015
} 
In this sense, our study focused on evaluating the effect of nitrogen fertilization via composted sewage sludge on wheat crop, instead of conventional nitrogen fertilization (or chemical), as well as assessing the effect of increasing doses of this compound.

\section{MATERIAL AND METHODS}

The experiment was carried out in pots under greenhouse conditions in the Department of Soils and Environmental Resources from the College of Agricultural Sciences of the University of São Paulo State (UNESP), campus in Botucatu-SP, Brazil. It started after the third application of composted sewage sludge (CSS), once pots had been fertilized with residues for wheat and soybean cultivation for successive cycles, whose sowings were performed in May and November 2011, respectively. The soil used to fill pots is originally classified as a dystrophic Red-Latosol (Oxisol) (EMBRAPA, 2006).

The CSS was provided by a sewage treatment plant (STP) located in the city of Jundiaí-SP, Brazil. In this STP, the generated sewage sludge is mixed with eucalyptus bark, crushed remains of urban pruning, and sugarcane bagasse. This mixture undergoes thermophilic composting with mechanical ventilation, resulting in an organic compost of sewage sludge allowed by the Brazilian Ministry of Agriculture and Livestock - MAPA. Compost chemical properties were analyzed in the Laboratory of Fertilizers and Liming, in the same university, following the method proposed by LANARV (1988), and results are shown in Table 1.

TABLE 1. Chemical composition of the composted sewage sludge (CSS).

\begin{tabular}{|c|c|c|c|c|c|c|c|c|}
\hline $\mathrm{N}$ & $\mathrm{P}_{2} \mathrm{O}_{5}$ & $\mathrm{~K}_{2} \mathrm{O}$ & $\mathrm{Ca}$ & $\mathrm{Mg}$ & $S$ & Hum. & O.M. & $\mathrm{C}$ \\
\hline 1.10 & 1.28 & 0.13 & 1.56 & 0.22 & 1.09 & 43.63 & 20.16 & 11.20 \\
\hline $\mathrm{Na}$ & B & $\mathrm{Cu}$ & $\mathrm{Fe}$ & $\mathrm{Mn}$ & $\mathrm{Zn}$ & & $\mathrm{C} / \mathrm{N}$ & $\mathrm{pH}$ \\
\hline 1658 & 123 & 179 & 1439 & 161 & 870 & & $10 / 1$ & 6.20 \\
\hline
\end{tabular}

To analyze the experiment, it was used a completely randomized design with seven treatments and ten replications, totaling 70 pots or experimental units (plots), following randomization principle (BANZATTO \& KRONKA, 2008). Treatments were defined as: T0 = without fertilization; $\mathrm{T} 1=100 \%$ mineral fertilization $\left(80 \mathrm{~kg} \mathrm{~N} \mathrm{ha}^{-1}\right.$ via urea); $\mathrm{T} 2=50 \%$ mineral fertilization $+50 \%$ CSS application (totaling $\left.80 \mathrm{~kg} \mathrm{~N} \mathrm{ha}^{-1}\right)$; T3 $=100 \%$ CSS $\left(80 \mathrm{~kg} \mathrm{~N} \mathrm{ha}^{-1} \mathrm{~N}\right)$; T4 $=150 \%$ CSS $\left(120 \mathrm{~kg} \mathrm{~N} \mathrm{ha}^{-1}\right) ; \mathrm{T} 5=200 \% \mathrm{CSS}\left(160 \mathrm{~kg} \mathrm{~N} \mathrm{ha}^{-1} \mathrm{de} \mathrm{N}\right)$; and T6 $=250 \% \mathrm{CSS}\left(200 \mathrm{~kg} \mathrm{~N} \mathrm{ha}^{-1}\right)$.

Nitrogen fertilization in T1, T2 and T3 was based on the recommended dose for wheat full development (RAIJ et al., 1997). In treatments receiving CSS, fertilization rates were set as role of partial, total or above recommended dose by nitrogen equivalent present in the compost.

Sludge amounts were calculated according to the content of nitrogen in this organic material and its mineral fraction (30\%), once the rates established by the CONAMA standard $\mathrm{n}^{0} 375 / 2006$ are grounded on north American values, which are specific to soils from temperate regions not from tropical ones (ANDRADE et al., 2010). Table 2 shows the amount of CSS applied to each treatment, considering that in $100 \mathrm{~kg}$ sludge, on a dry basis, $1.1 \mathrm{~kg} \mathrm{~N}$ are applied (Table 1), within which $30 \%$ is mineralized in the first year. 
TABLE 2. Dose of composted sewage sludge applied to each treatment.

\begin{tabular}{ccc}
\hline Treatment & \multicolumn{2}{c}{ Composted Sewage Sludge } \\
\cline { 2 - 3 } & $\mathrm{g} \mathrm{pot}^{-1}(*)$ & $\mathrm{t} \mathrm{ha}^{-1}(* *)$ \\
T2 & 153 & 12 \\
T3 & 305 & 24 \\
T4 & 458 & 36 \\
T5 & 610 & 48 \\
T6 & 763 & 60 \\
\hline
\end{tabular}

*Actual amount applied, **Equivalent dose.

All treatments received complementary fertilization with $\mathrm{P}_{2} \mathrm{O}_{5}$ and $\mathrm{K}_{2} \mathrm{O}$ (RAIJ et al., 1997) in order to standardize the amounts of $\mathrm{P}\left(150 \mathrm{mg} \mathrm{dm}^{-3}\right)$ and $\mathrm{K}\left(80 \mathrm{mg} \mathrm{dm}^{-3}\right)$ in the soil.

Wheat seeds of 'CD150' cultivar (Cooperativa Central de Pesquisa Agrícola, Cascavel-PR, Brazil), derived from crossing 'CD104' and 'CD108', were sown on pots (30 seeds per pot) on May 21, 2012. This cultivar is small in height, averaging $68 \mathrm{~cm}$, being moderately susceptible to powdery mildew. After emergence, thinning was carried out, leaving 24 plants per pot.

Water supply was daily made through drip irrigation, replacing the amount lost by crop evapotranspiration, which was also daily calculated based on data from a class A evaporation pan in the middle of the greenhouse.

In the course of the experimental phase, crop variables related to plant growth and yield were assessed at different times. At 60 days after emergence (DAE), we evaluated the number of tillers per plant - NTP. At physiological maturity (98 DAE), all 24 plants at each plot were collected for

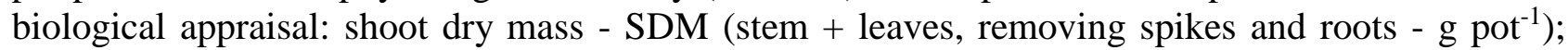
number of spikes per plant - NSP; spike length $(\mathrm{cm})$; number of spikelet per spike - NsS; number of grains per spike - NGS; grain mass per spike - GMS, which was corrected to $13 \%$ moisture (g); and grain yield per plant - GYP $(\mathrm{g})$, resulting from the ratio between total grain mass per pot and the number of plants within this unit.

Data were statistically analyzed through SISVAR software and underwent variance analysis at $5 \%$ probability, and means compared by the Tukey's test at 5\% de significance. In treatments that only received CSS, data were submitted to regression analysis. Significant results allowed us to build graphs that show each studied parameter behavior with increasing doses of the organic compost.

\section{RESULTS AND DISCUSSION}

It is noteworthy mention that all treatments promoted major changes on wheat yield and its components. Tillering was significantly superior in T5 and T6. Moreover, the highest doses of nitrogen promoted increases in NSP and in GYP, as seen in Tables 3 and 4, respectively. This positive response might be related to the fact that nitrogen is one of the most demanded nutrients by wheat plants, with the role, among others, of stimulating vegetative growth (FORNASIERI FILHO, 2008). 
TABLE 3. Average number of tillers per plant, spikes per plant, spikelets per spike and spike length.

\begin{tabular}{|c|c|c|c|c|c|}
\hline \multicolumn{6}{|c|}{ Treatments $^{(\mathbf{1})}$} \\
\hline T0 & $\mathbf{T 2}$ & T3 & $\mathbf{T 4}$ & $\mathbf{T 5}$ & T6 \\
\hline \multicolumn{6}{|c|}{ Tillers per plant } \\
\hline $1.07 \mathrm{e}$ & $2.61 \mathrm{bc}$ & $2.17 \mathrm{~cd}$ & $2.87 \mathrm{ab}$ & $3.36 \mathrm{a}$ & $3.36 \mathrm{a}$ \\
\hline \multicolumn{6}{|c|}{ C.V. $=17.90 \% ;$ Overall average $=2.49 ; \mathrm{SMD}=0.61 ; \mathrm{F}_{\text {calc. }}=34.043 * *$} \\
\hline \multicolumn{6}{|c|}{ Spikes per plant } \\
\hline $1.18 \mathrm{c}$ & $1.84 \mathrm{~b}$ & $1.80 \mathrm{~b}$ & $2.21 \mathrm{a}$ & $2.34 \mathrm{a}$ & $2.46 \mathrm{a}$ \\
\hline \multicolumn{6}{|c|}{ C.V. $=10.74 \% ;$ Overall average $=2.01 ; \mathrm{SMD}=0.29 ; \mathrm{F}_{\text {calc. }}=41.468 * *$} \\
\hline \multicolumn{6}{|c|}{ Spike length $(\mathrm{cm})$} \\
\hline $6.61 \mathrm{c}$ & $7.82 \mathrm{ab}$ & $7.96 \mathrm{a}$ & $8.35 \mathrm{a}$ & $8.21 \mathrm{a}$ & $8.03 \mathrm{a}$ \\
\hline \multicolumn{6}{|c|}{ C.V. $(\%)=5.65 ;$ Overall average $=7.75 ; \mathrm{SMD}=0.60 ; \mathrm{F}_{\text {calc }}=19.352 * *$} \\
\hline \multicolumn{6}{|c|}{ Spikelets per spike } \\
\hline $12.90 \mathrm{c}$ & $14.23 \mathrm{bc}$ & $15.17 \mathrm{ab}$ & $16.37 \mathrm{a}$ & $16.00 \mathrm{a}$ & $15.23 \mathrm{ab}$ \\
\hline
\end{tabular}

(1) T0, without fertilization; T1, 100\% mineral fertilization; T2, 50\% mineral fertilization + 50\% CSS; T3, T4, T5, and T6 corresponding to $100,150,200$, and $250 \%$ of nitrogen fertilization from CSS, respectively. C.V. = coefficient of variation; SMD = significant minimum difference; Means followed by the same lower case letter within a line do not differ from each other by the Tukey's test at $5 \%$ probability. ${ }^{* *}$ Significant at $5 \%$ probability.

Figure 1 demonstrates tillering averages adjusted to a quadratic equation upwardly as organic compost doses rose, pointing out a positive response by wheat plants shown through number of tillers (3.36) up to a dose of $200 \%$ CSS, which is equivalent to $160 \mathrm{~kg} \mathrm{~N} \mathrm{ha}^{-1}$. Similarly, NUNES et al. (2011) observed an increase in number of tillers with growing doses of mineral fertilizer $(0,30$, $60,90,120$, and $150 \mathrm{~kg} \mathrm{~N} \mathrm{ha}^{-1}$ ) reaching a maximum value (3.47) with $110 \mathrm{~kg} \mathrm{~N} \mathrm{ha}^{-1}$, unlike observed here.
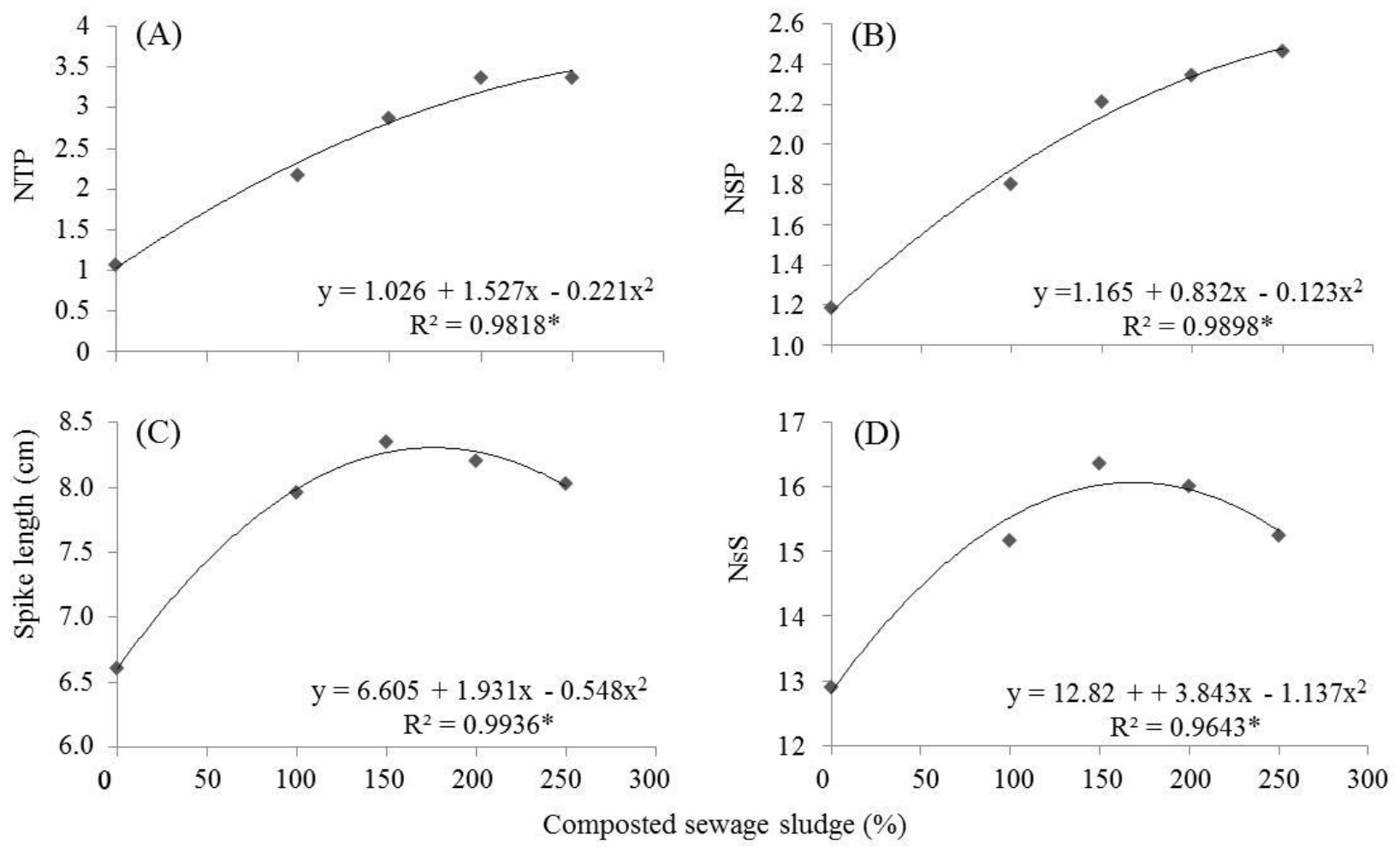

FIGURE 1. Number of tillers per plot (A), number of spikes per plant (B), spike length (C) and number of spikelets per spike (D) with increasing doses of composted sewage sludge of $0,100,150,200$, and $250 \%$, equivalent to $0,80,120,160$, and $200 \mathrm{~kg} \mathrm{~N} \mathrm{ha}$. *Significant at $5 \%$ probability. 
Spike length and NsS had the highest averages in T4 (200\% CSS), although these results had no statistical difference compared to T2, T3, T5, and T6 (Table 3). The regression model that best fit results of NSP, spike length, and NsS with doses of CSS without mineral supplementation was quadratic, with increasing values of NSP up to a dose of $200 \mathrm{~kg} \mathrm{~N} \mathrm{ha}^{-1}$ via CSS (Figure 1). The model fit equation enabled us to set points of maximum response (8.31 and 16.07) at doses of 140.8 $\mathrm{kg} \mathrm{N} \mathrm{ha}^{-1}(176 \% \mathrm{CSS})$ and $135.2 \mathrm{~kg} \mathrm{~N} \mathrm{ha}^{-1}$ (169\% CSS) for spike length and NsS, respectively.

Likewise, TEIXEIRA FILHO et al. (2007) observed that N supplementation had influence on both the number of spikelets per spike and on spike lengths until doses of 60 and $69 \mathrm{~kg} \mathrm{~N} \mathrm{ha}^{-1}$, respectively. On the other hand, TEIXEIRA FILHO et al. (2008) reported no significant differences when assessing wheat spike length, NsS, and NGS at various nitrogen doses $(0,30,60,90,120$, and $150 \mathrm{~kg} \mathrm{~N} \mathrm{ha}^{-1}$ ). Such difference may be due to soil conditions, application manner and source of $\mathrm{N}$ used.

TABLE 4. Averages of shoot dry matter (SDM), number of grains per spike (NGS), grain mass per spike (GMS) and grain yield per plant (GYP).

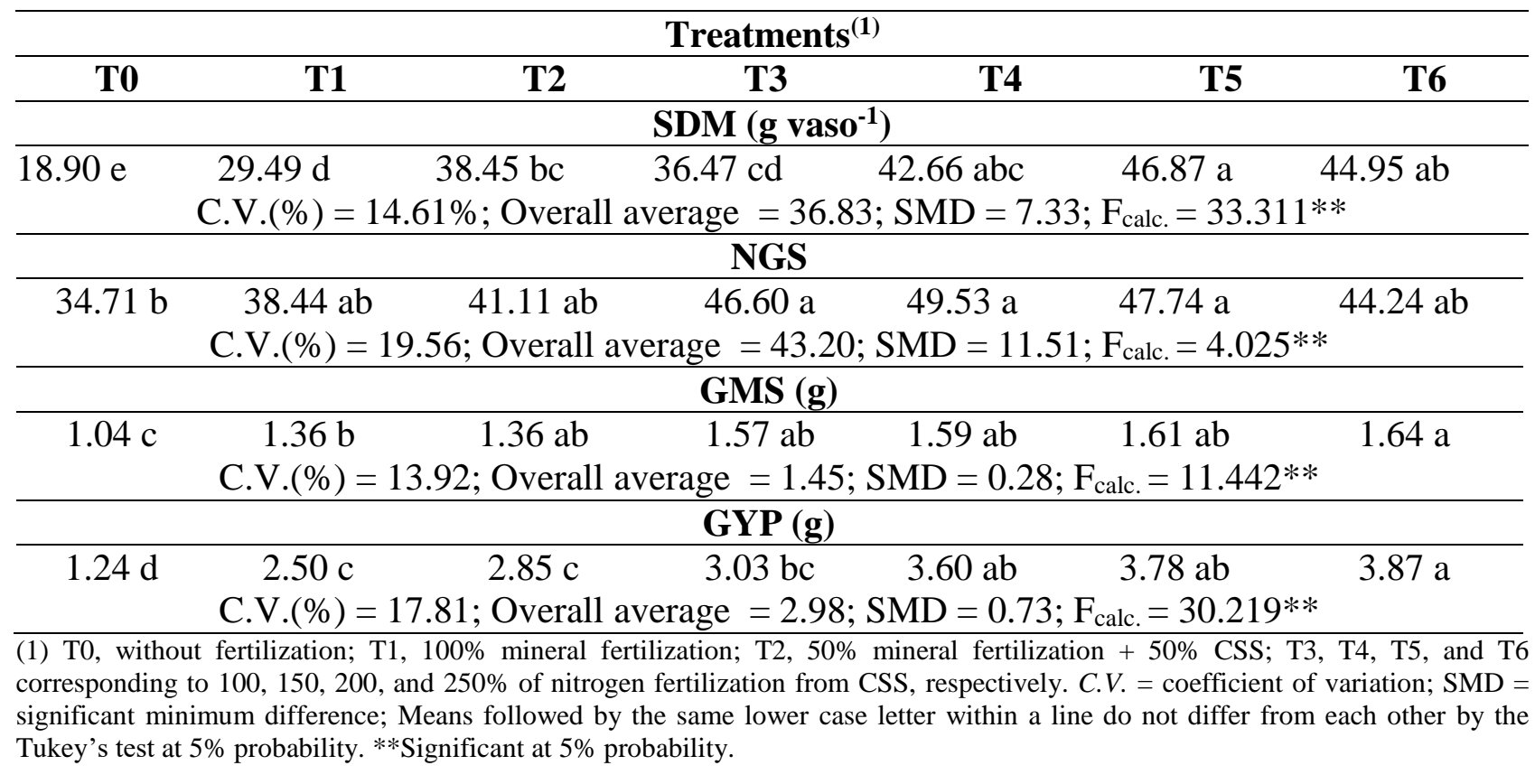

As shown in Tables 3 and 4, except for NTP and GYP, all variables showed no statistical variation between T6 and T2 (50\% CSS plus 50\% urea). This result indicates that a simultaneous application of these fertilizers (organic and mineral) may produce satisfactory results to this crop, ensuring a saving of at least $50 \%$ in mineral fertilizer.

When comparing $\mathrm{T} 1, \mathrm{~T} 2$, and $\mathrm{T} 3$, which received the same amount of $\mathrm{N}$ through different sources and combinations of them, variables presented a distinct behavior, as shown in Tables 3 and 4. Under these circumstances, the highest values of NTP, NSP and SDM were observed for T2, in which mineral fertilization $(50 \%)$ was blended with organic $(50 \%)$ via CSS. Moreover, it is noteworthy that when using $100 \% \mathrm{CSS}$, there was a higher dry matter accumulation if compared to $100 \%$ mineral fertilization.

Overall, for the other variables spike length, NsS, NGS, GMS, and GYP, we observed that $100 \%$ CSS had values statistically equivalent to those of mineral fertilization (T1). Likewise, CERDA et al. (2004), who investigated dehydrated and liquid sewage sludge uses on wheat at doses of 4 and $8 \mathrm{t} \mathrm{ha}^{-1}$ on a dry basis, observed a highest dry matter yield with liquid sludge $\left(8 \mathrm{t} \mathrm{ha}^{-1}\right)$. These same authors reported that grain yields were similar for treatments using dehydrated sludge and inorganic fertilizers. Nevertheless, CHUEIRI et al. (2007), studying alkaline sewage sludge (ASS) as mineral fertilization supplement, concluded that ASS had a negative effect on morphological parameters and dry matter yield of wheat plants. The differences between both 
studies may particularly rely on chemical characteristics of the used organic residues, which vary according to the source used.

Regression model that has best fit SDM was the quadratic, with a maximum response point (43.90) at $182.4 \mathrm{~kg} \mathrm{~N} \mathrm{ha}^{-1}$ via CSS (Figure 2). According to SCHRÖDER et al. (2000), such increasing in SDM values at different nitrogen doses were already expected, once $\mathrm{N}$ promotes vegetative growth of plants, playing an important role on first leaf expansion, as well as on final leaf sizes and stem elongation.
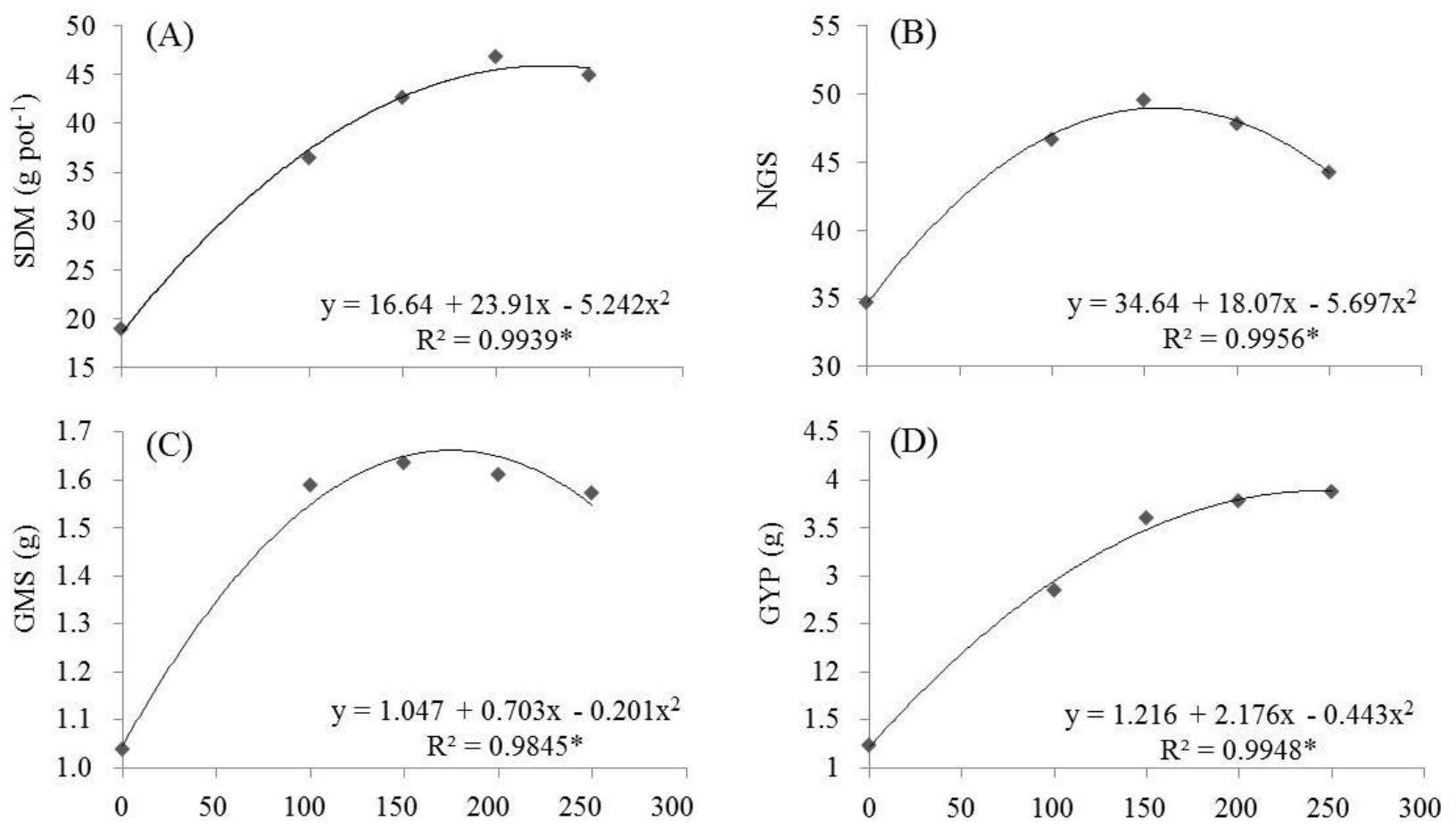

Composted sewage sludge (\%)

FIGURE 2. Shoot dry matter (A), number of grains per spike (B), grain mass per spike (C), and grain yield per plant (D) with increasing doses of composted sewage sludge of 0,100 , 150,200 , and $250 \%$, equivalent to $0,80,120,160$, and $200 \mathrm{~kg} \mathrm{~N} \mathrm{ha}^{-1}$. *Significant at $5 \%$ probability.

GMS and NGS regression analysis showed a quadratic adjustment, whose maximum response points were 48.97 and 1.66 at doses of 127.2 and $140 \mathrm{~kg} \mathrm{~N} \mathrm{ha}^{-1}$ via CSS, respectively (Figure 2). Similar findings were reported by CAZETTA et al. (2007), who said that the number of grains per spike increased linearly with growing doses of $\mathrm{N}\left(0,30,60,90\right.$, and $\left.120 \mathrm{~kg} \mathrm{ha}^{-1}\right)$, presenting higher averages at the maximum dose.

In terms of grain yield, a maximum response (3.89) was observed when using $246 \%$ CSS $\left(196.8 \mathrm{~kg} \mathrm{~N} \mathrm{ha}^{-1}\right)$. It is best seen in Figure 2, in which the means were fit to a quadratic equation, with an increase in grain yield as a function of growing quantities of sludge. These outcomes are similar to those found by PIETRO-SOUZA et al. (2013). In contrast, PENCKOWSKI et al. (2009) observed that different $\mathrm{N}$ doses $\left(90,135,180,225 \mathrm{~kg} \mathrm{ha}^{-1}\right)$ had no significant effect on number of tillers, spikes per square meter, spikelets per spike, grains per spike, and yield, thus concluding that production components were not affected by increasing $\mathrm{N}$ rates.

As stated by TEIXEIRA FILHO et al. (2010), low doses of N limit crop productivity whilst high doses may decrease that, which might bring losses to farmers once unnecessary costs with mineral fertilizations are remained. For ZAGONEL et al. (2002) and PENTKOWNKI et al. (2009), high $\mathrm{N}$ doses bring yield increases, however, may result in plant lodging that occurring during grain filling restricts carbohydrate translocation in plants, interfering with production and grain quality. 
The regression analysis pointed out that most of the variables showed a decreasing behavior in response to a maximum dose of CSS (250\% of N recommended dose) (Figures 1 and 2). Other studies have shown similar results with respect to raising rates of mineral $\mathrm{N}$ in the soil (ESPÍNDULA et al., 2010; NUNES et al., 2011; PRANDO et al., 2012).

NUNES et al. (2011), aiming at assessing green manure associated with mineral fertilizing ( 0 , $30,60,90,120$, and $150 \mathrm{~kg} \mathrm{~N} \mathrm{ha}^{-1}$ ) in topdressing of wheat under no-tillage, found a decrease in the adjustment curve of quadratic regression for grain yield and number of tillers, at the highest dose of $\mathrm{N}\left(150 \mathrm{~kg} \mathrm{ha}^{-1}\right)$. Yet ESPÍNDULA et al. (2010) observed a linear increase for number of grains per spike, number of spikes per square meter, and shoot dry mass, up to a dose of $120 \mathrm{~kg} \mathrm{~N} \mathrm{ha}^{-1}$. Yield averages adjusted to a quadratic model with maximum responses between doses of 80 and $100 \mathrm{~kg}$ $\mathrm{ha}^{-1}$, after which dropped up to the maximum dose (120 $\left.\mathrm{kg} \mathrm{ha}^{-1}\right)$. PRANDO et al. (2012) also noted a linear increase for number of spikes per square meter and grain yield up to a dose of $120 \mathrm{~kg} \mathrm{ha}^{-1}$.

The reduction on these variables due to high $\mathrm{N}$ doses may be associated with the high content of organic matter released by CSS, altering the $\mathrm{C} / \mathrm{N}$ ratio in the soil, limiting nitrogen supply to the plants (VICTORIA et al., 1992). This restriction inhibits wheat response to high doses of $\mathrm{N}$ that were provided via CSS.

Finally, in T0, all variables had low performance when compared to other treatments, which was expected since no source of nitrogen was provided to the plants.

\section{CONCLUSIONS}

- The combination of $50 \%$ composted sewage sludge with $50 \%$ urea, substituting $100 \%$ mineral fertilization, promoted significant increases on the number of tillers per plant, number of spikes per plant, and shoot dry matter in wheat plants.

- Changing the conventional nitrogen fertilization by applying composted sewage sludge increased averages of number of tillers per plant, spike length, number of spikelets per spike, shoot dry matter, number of grains per spike, and grain mass per spike promoting greater grain yields;

- Spike length, number of spikelets per spike, number of grains per spike, and grain mass per spike were satisfactory up to a dose of $160 \mathrm{~kg} \mathrm{~N} \mathrm{ha}^{-1}$ applied via composted sewage sludge, declining in superior doses.

- The maximum dose of $200 \mathrm{~kg} \mathrm{~N} \mathrm{ha}^{-1}$ applied via composted sewage sludge contributed to increased grain yields.

\section{ACKNOWLEDGEMENTS}

The authors want to thank the CNPq and to the Post-Graduation Program in Irrigation and Drainage of the FCA/ UNESP, in Botucatu-SP, Brazil, by granting financial support.

\section{REFERENCES}

ANDRADE, C. A.; OLIVEIRA, C.; CERRI, C. C. Qualidade da matéria orgânica e estoques de carbono e nitrogênio em Latossolo tratado com biossólido e cultivado com eucalipto. Revista Brasileira de Ciência do Solo, Viçosa, MG, v.29, n.5, p.803-816, 2005.

ANDRADE, C.A., BOEIRA, R.C., PIRES, A.M.M. Nitrogênio presente em lodo de esgoto e a resolução no 375 do Conama. In: COSCIONE, A. R.; NOGUEIRA, T. A. R.; PIRES, A. M. M. Uso agrícola de lodo de esgoto: avaliação após a resolução n ${ }^{\circ} 375$ do Conama. Botucatu: Editora FEPAF, 2010. p. 157-170.

BANZATTO, D. A.; KRONKA, S. do N. Experimentação agrícola. 4. ed. Jaboticabal: Funep, 2008. 237 p. 
BEHLING, M.; DIAS, F. C.; SOBRINHO, N. M. B. A.; OLIVEIRA, C.; MAZUR, N. Nodulação, acúmulo de nitrogênio no solo e na planta e produtividade de soja em solo tratado com lodo de estação de tratamento de resíduos industriais. Bragantia, Campinas, v. 68, p.453-462, 2009.

BOEIRA, R. C. Uso do lodo de esgoto como fertilizante orgânico: disponibilização de nitrogênio em solos tropical. Jaguariúna: Embrapa Meio Ambiente, 2004. (Comunicado Técnico, 12).

CAZETTA, D. A.; FORNASIERI FILHO, D.; ARF, O. Resposta de cultivares de trigo e triticale ao nitrogênio no sistema de plantio direto. Científica, Jaboticabal, v.35, n.2, p.155-165, 2007.

CERDA, M.; OLIVARES-SAÉNZ, E.; SALINAS-GRACÍA, G.; ZÁVALA-GARCÍA, F.; ARANDA-RUIZ, J. Efecto residual del lodo em trigo (Triticum spp. L.). Phyton, v.73, ene./dic. 2004. Buenos Aires, Vicente López (Argentina), 2004.

CHIBA, M. K.; MATTIAZZO, M. E.; OLIVEIRA, F. C. Cultivo de cana-de-açúcar em argilossolo tratado com lodo de esgoto. II - fertilidade do solo e nutrição da planta. Revista Brasileira de Ciência do Solo, Viçosa, MG, v. 32, p.653-662, 2008.

CHUEIRI, W. A.; SERRAT, B. M.; BIELE, J.; FAVARETTO, N. Lodo de esgoto e fertilizante mineral sobre parâmetros do solo e plantas de trigo. Revista Brasileira de Engenharia Agrícola e Ambiental, Campina Grande, v.11, n.5, p.502-508, 2007.

COELHO, H. A.; GRASSI FILHO, H.; ROMEIRO, J. C. T.; POMPERMAYER, G. V.; BARBOSA, R. D.; LOBO, T. F. Desempenho agronômico do lodo de esgoto como fonte de nitrogênio em bananeiras. Revista Agrarian, Dourados, v.4, n.13, p.172-181, 2011.

CONAMA - Conselho Nacional do Meio Ambiente. Resolução no 375/2006, de 29/8/2006. Disponível em: <http://www.mma.gov.br/port/conama/legiano/>. Acesso em: 13 jul. 2013.

COSTA, L.; ZUCARELI, C.; RIEDE, C. R. Parcelamento da adubação nitrogenada no desempenho produtivo de genótipos de trigo. Revista Ciência Agronômica, Fortaleza, v.44, n.2, p.215-224, abr.-jun. 2013.

EMBRAPA - EMPRESA BRASILEIRA DE PESQUISA AGROPECUÁRIA. Sistema brasileiro de classificação de Solos. Rio de Janeiro: Embrapa Solos, 2006. 306p.

ESPÍNDULA, M. C.; ROCHA, V. S.; SOUZA, M. A.; GROSSI, J. A. S.; SOUZA, L. T. Doses e formas de aplicação de nitrogênio no desenvolvimento da cultura do trigo. Ciência e Agrotecnologia, Lavras, v.34, n.6, p.1401-1411, nov./dez. 2010.

FIGUEIRÊDO, I. C. M.; LIMA, V. L. A.; BELTRÃO, N. E. M.; ARAÚJO, M. G. F.; SANTOS, T. S.; AZEVEDO, C. A. V. Uso da água residuária tratada e do biossólido no algodão colorido: produção e seus componentes. Revista Brasileira de Engenharia Agrícola e Ambiental, Campina Grande, v. 9, p. 288-291, 2005.

FORNASIERI FILHO, D. Manual da cultura do trigo. Jaboticabal: Funep, 2008. 338p.

LANARV - LABORATÓRIO NACIONAL DE REFERÊNCIA VEGETAL. Análise de corretivos, fertilizantes e inoculantes: métodos oficiais do Laboratório Nacional de Referência Vegetal. Brasília, 1988. 104 p.

LOBO, T. F.; GRASSI FILHO, H.; BULL, L. T. Rendimento de massa de matéria seca e relação $\mathrm{C} / \mathrm{N}$ da aveia preta em função do lodo de esgoto e adubação nitrogenada. Bioscience Journal, Uberlândia, v.28, n.2, p.224-234, mar./abr. 2012a.

LOBO, T. F.; GRASSI FILHO, H.; BULL, L. T.; KUMMER, A. C. B. Efeito do lodo de esgoto e do nitrogênio nos fatores produtivos do girassol. Revista Brasileira de Engenharia Agrícola e Ambiental, Campina Grande, v.17, n.5, p.504, 2013.

LOBO, T. F.; GRASSI FILHO, H.; CARDOSO, E. J. B. N.; ALMEIDA, L. de S.; NOMIYAMA JUNIOR, N. Crescimento e fixação biológica do nitrogênio em soja cultivada com doses de lodo de esgoto compostado. Semina: Ciências Agrárias, Londrina, v.33, n.4, p.1333-1342, jul./ago. 2012 b. 
NOGUEIRA, T. A. R.; OLIVEIRA, L. R.; MELO, W. J.; FONSECA, I. M.; MELO, G. M. P.; MELO, V. P.; MARQUES, M. O. Cádmio, cromo, chumbo e zinco em plantas de milho e em Latossolo, após nove aplicações anuais de lodo de esgoto. Revista Brasileira de Ciência do Solo, Viçosa, MG, v.32, n.5, p.2195-2207, 2008.

NUNES, A. S.; SOUZA, L. C.; VITORINO, A. C. T.; MOTA, L. H. S. Adubos verdes e doses de nitrogênio em cobertura na cultura do trigo sob plantio direto. Semina: Ciências Agrárias, Londrina, c.32, n.4, p.1275-1384, out-dez. 2011.

PELISSARI, R. A. Z.; SAMPAIO, S. C.; GOMES, S. D.; CREPALLI, M. S. Lodo têxtil e água residuária da suinocultura na produção de mudas de eucalyptus grandis (W, Hill ex Maiden). Revista Engenharia Agrícola, Jaboticabal, v.29, n.2, p.288-300, abr./jun. 2009.

PENCKOWSKI, L. H.; ZAGONEL, J.; FERANDES, E. C. Nitrogênio e redutor de crescimento em trigo de alta produtividade. Acta Scientiarum Agronomy, Maringá, v.31, n.3, p.473-479, 2009.

PIETRO-SOUZA, W.; BOMFIM_SILVA, E. M.; SCHLICHTING, A. F.; SILVA, M. C.

Desenvolvimento inicial de trigo sob doses de nitrogênio em Latossolo vermelho de Cerrado.

Revista Brasileira de Engenharia Agrícola e Ambiental, Campina Grande, v.17, n.6, p.575-580, 2013.

PRANDO, A. M.; ZUCARELI, C.; FRONZA, V.; BASSOI, M. C.; OLIVEIRA, F. A. Formas de uréia e doses de nitrogênio em cobertyura no desempenho agronômico de genótipos de trigo.

Semina: Ciências Agrárias, Londrina, v.33, n.2, p.621-632, 2012.

RAIJ, B. van; CANTARELLA, H.; QUAGGIO, J.A.; FURLANI, A.M.C. Recomendações de adubação e calagem para o Estado de São Paulo. 2.ed. Campinas: Instituto Agronômico/ Fundação IAC, 1997. 285p

SCHRÖDER, J. J.; NEETESON, J. J.; OENEMA, O.; STRUIK, P. C. Does the crop or the soil indicate how to save nitrogen in maize production?: Reviewing the state of the art. Field Crops Research, Amsterdam, v.66, p.151-164, 2000.

TEIXEIRA FILHO, M. C. M.; BUZETTI, S.; ALVAREZ, R. C. F.; FREITAS, J. G.; ARF, O. SÁ, M. E. Desempenho agronômico de cultivares de trigo em resposta a população de plantas e a adubação nitrogenada. Científica, Jaboticabal, v.36, n.2, p.97-106, 2008.

TEIXEIRA FILHO, M. C. M.; BUZETTI, S.; ANDREOTTI, M.; ARF, O.; BENETT, C. G. S. Doses, fontes e épocas de aplicação de nitrogênio em trigo irrigado em plantio direto. Pesquisa Agropecuária Brasileira, Brasília, v.45, n.8, p.797-804, ago. 2010.

TEIXEIRA FILHO, M. C. M.; BUZETTI, S.; ALVAREZ, R. C. F.; FREITAS, J. G.; ARF, O.; SÁ, M. E. Resposta de cultivares de trigo irrigados por aspersão ao nitrogênio em cobertura na região do Cerrado. Acta Scientiarum Agronomy, Maringá, v.29, n.3, p.421-425, 2007.

TEIXEIRA, S. T.; MELO, W. J.; SILVA, E. T. Plant nutrients in a degraded soil treated with water treatment sludge and cultivated with grasses and leguminous plants. Soil Biology \& Biochemistry, Elmsford, v.39, p.1348-1354, 2007.

VIANA, E. M.; KIEHL, J. C. Doses de nitrogênio e potássio no crescimento do trigo. Bragatinga, Campinas, v.69, n.4, p.975-982, 2010.

VICTORIA, R. L.; PICCOLO, M. C.; VARGAS, A. A. T. O ciclo do nitrogênio. In: CARDOSO, E. J. B. N. Microbiologia do solo. Campinas: Sociedade Brasileira de Ciência do Solo, 1992. p. 105119.

ZAGONEL, J.; VENANCIO, W. S.; KUNZ, R. P.; TANAMATI, H. Doses de nitrogneio e densidade de plantas com e sem um regulador de crescimento afetando o trigo, cultivar OR-1.

Ciência Rural, Santa Maria, v. 22, n.1, p.25-29, 2002. 


\title{
ERRATUM
}

In the paper "COMPOSTED SEWAGE SLUDGE IN REPLACEMENT OF MINERAL FERTILIZATION ON WHEAT PRODUCTION AND DEVELOPMENT", with DOI number: 10.1590/1809-4430-Eng.Agric.v36n4p706-714/2016, published in the journal Agricultural Engineering 36 (4):706-714, on the page 706:

Where it reads:

\author{
ANA C. B. KUMMER ${ }^{*}$, HELIO GRASSI FILHO ${ }^{3}$, THOMAZ F. LODO ${ }^{4}$, \\ RODOLLPHO A. DE S. LIMA ${ }^{5}$
}

It should read:

ANA C. B. KUMMER ${ }^{*}$, HELIO GRASSI FILHO ${ }^{3}$, THOMAZ F. LOBO ${ }^{4}$, RODOLLPHO A. DE S. LIMA 